\title{
Beta Rasa: Emotion Regulation Program to Reduce Young Offenders Anxiety in LPKA Kupang
}

\author{
Juliana Marlin Y. Benu', Rizky Pradita Manafe ${ }^{2}$, Engelina Nabuasa ${ }^{3}$ \\ ${ }^{1,2,3}$ Faculty of Psychology, Universitas Nusa Cendana
}

Submitted 14 Agustus 2020 Accepted 13 April 2021 Published 28 May 2021

\begin{abstract}
Anxiety is one of the emotional problems experienced by young offenders in LPKA (Lembaga Pembinaan Khusus Anak/Juvenile Detention Center) Kupang and this condition has a negative impact on their rehabilitation process. The condition requires psychological intervention. This research aimed to understand the impact of the Beta Rasa Program in reducing anxiety. Beta Rasa Program focuses on improving young offender's emotional regulation ability. This research was a quasi-experiment with one group pretest-posttest design. In total, there were 20 young offenders participating in this program for 4 sessions. Paired sample t-test was used to analyze data in this research. Young offender's anxiety was measured by Beck Anxiety Inventory (BAI). The research showed a significant decrease in young offenders' anxiety $(t=2.116, p=0.02)$ after they joined Beta Rasa Program. The effect size of this program was 0.41 . The result indicates that Beta Rasa Program has a moderate effect to reduce anxiety.
\end{abstract}

Keywords: anxiety; emotional regulation; young offenders

LPKA (Lembaga Pembinaan Khusus Anak/Juvenile Detention Center) is an Indonesian public institute for children and adolescents who committed criminal conducts. LPKA Kupang (at the time of this study) housed 36 male young offenders (Direktorat Jenderal Permasyarakatan, 2019). They were involved in different cases such as sexual assault (83\%), homicide $(11 \%)$, and thieving $(6 \%)$. Young offenders in LPKA Kupang received different sentences, with minimum 18 months and maximum 10 years of jail period. A long period in jail can cause many psychological problems with young offenders. Getting bored as well as worrying about future and their family became major complains of the young offenders. Earlier study by Benu et al. (2019) showed that young offenders in LPKA Kupang often experienced a lot of negative emotions such as anger, sadness, boredom, and worry in their daily life. This result was also consistent with research from Hadjam (2014) which stated that uncertainty, worry, and other negative emotions are the main emotional problems of people in jail. Several studies also pinpoint that anxiety is one of major problems for inmates (Robertson et al., 2020; Hamzah et al., 2020)

At normal level, anxiety is a common emotion experienced by human. Anxiety becomes a problem when the person cannot manage such emotion properly or when the anxiety occurs every day. According to Neumann (in Speilberger \& Sarason, 1986), anxiety arises when the person becomes aware of threats to concerns that are vital to them. There are two types of anxiety known. They are trait anxiety and state anxiety. Trait anxiety refers to the 
personality that is prone to experience anxiety. State anxiety reflects the psychological or physiological reaction related to certain situations or specific moments. This research focused on state anxiety because prison considered as high risk environment (WHO \& ICRC, 2014).

The main symptom of anxiety can be seen in three main category, there are cognitive, physical, and behavior symptoms (Stanley et al., 2004; Craske et al., 2009). Beck (1993) reported several signs of anxiety such as numbness, incapability of relaxing, fear of the worst may happen, nervous, trembling, difficulty of breathing, fainting, and so on. These symptoms could be observed in young offenders on LPKA Kupang. Previous study from Benu et al. (2019) stated that young offenders in the LPKA showed various signs of anxiety such as frightened, over worry about their future, high tension of physical arousal such as stomachache, dizziness, heart pounding or racing, trembling, sweating, difficulty to fall asleep, unpurposive behavior, and restlessness. This finding also was confirmed by researcher's observation and interview process with young offenders and officers in LPKA Kupang for two months. Study by Haghighat et al. (2014) showed that anxiety experienced by prisoners became a supportive factor of substance abuse, sleep problems, and depression.

Wenar and Kerig (2000) stated that children with high level of anxiety often receive unresponsive parenting style. Parenting that involves avoidance or ignorance of children emotional outbursts can lead to the inability of learning how to express emotion properly. Children who did not fully learn about expressing emotion properly tend to have poor emotion regulation in their adolescence period (Gruhn \& Compas, 2020; Milojevich et al., 2020). When a child did not learn to fully understand their emotion, they will have problem to regulate their emotions.

Emotion regulation refers to a people's ability to control negative emotions and improve favorable emotions (Heinzen et al., 2011). Emotion regulation is defined broadly as the capacity to manage one's own emotional responses. This includes strategies to increase, maintain, or decrease the intensity, duration, and trajectory of positive and negative emotions (Young et al., 2019). Gross (2015) defined emotion regulation as an attempt to influence which emotions someone is experiencing, when that person has it, and how one experiences or expresses these emotions. Gross (2015) also described two strategies to regulate emotions; (1) cognitive reappraisal (attempt to reinterpret emotional triggers to change its impact) and (2) expressive suppression (the inhibition of emotional expression so as not to communicate information about one's emotional state).

Studies showed that incarcerated people often have problem with emotion regulation. Study by Velotti et al. (2016) showed that young offenders have limited capability of being aware and regulating their emo. These conditions effect their ability to control their anger to unpredictable events. Study also showed that emotion regulation is one of sexual abuse's causes in adolescence (Chaplo et al., 2015). Study done by Heinzen et al. (2011) found strong correlation between poor emotional regulations and behavioral problem in young offenders. Studies also found that young sex offenders tend to had poor self-control especially in 
emotion regulation aspect (Kingston et al., 2012). Observation (from January - February 2019) on young offenders in LPKA Kupang showed that they tend to have inferior emotion regulation. In the earlier assessment, they perceived the word "emotion" as similar to angry. At behavior level, they showed quick reaction to threatening situations. It caused them to often engage in conflicts with other young inmates.

Offenders who committed crime at such young age need help to increase their ability to regulate emotion. Research showed that intervention to improve emotion regulation can be a protective factor to cope with depression and anxiety disorder (Compare et al., 2014). This research is consistent with other findings stating that emotion regulation therapy is effective to overcome generalized anxiety disorder (Mennin et al., 2015; Renna et al., 2018). A study showed that emotion regulation therapy brings positive effect to people with psychological issues. Someone who received emotion regulation training tends to experience more positive emotions (Lennarz et al., 2018). The dominance of positive emotions in the person's life can help to reduce their anxiety (Demorest, 2019).

In Indonesia, there are several studies that examine various forms of emotion regulation intervention. Two studies focused on how emotional regulation training can help to reduce aggressive behavior (Syahadat, 2013; Yunialia \& Suharto, 2020). Another study focused on how emotion regulation training can reduce stress in diabetic patients (Patrika, 2018). At the time this article was written, no study in Indonesia that focusing on anxiety among young inmates had been done.

Young offenders in LPKA Kupang were shown anxiety symptoms and poor emotional regulation (Benu et al., 2019). Therefore, emotion regulation needs to be taught for young offenders in LPKA Kupang. Although the need for emotional regulation intervention was identified, the coaching process at LPKA has not yet facilitated the psychological aspects of young offenders. To facilitated emotional regulation intervention needs, researcher than develop a Beta Rasa Program.

Beta Rasa Program is an emotional regulation program developed based on emotion regulation technique by Knell (2009). This program focused on helping young inmates to learn about emotions and how to regulate their emotions in a better way. Knell (2009) stated that there are three main steps to develop a proper emotion regulation. The first step is to have proper knowledge and understanding about emotions, the second is ability to identify emotional triggers or events, and the last one is learning the proper coping skill. The researcher then developed these three steps into four-session program. For the first two sessions, the program focused on increasing young offender's knowledge and understanding about emotion. During the first session, the inmates learned various types of emotions. In the second session, young inmates learned to be more aware of their own emotions by using emotion tracking sheet (Thermometer Rasa). In the third session, the inmates learned to identify and be more cautious with emotional triggers. The last session focused on developing their coping skill. 
The aim of this study was to understand the effect of Beta Rasa as an emotion regulation program to reduce young offender's anxiety. The hypothesis proposed in this study was "Beta Rasa as emotion regulation program can reduce young offender's Anxiety".

\section{Method}

\section{Participants}

There were 36 young offenders in LPKA Kupang at the time this research was conducted. All participants in this study were male, aged between $14-21$ years old, with a varying offenses such as sexual abuse, homicide, and robbing. Not all the participants can join the entire sessions for some reasons (e.g.: had to attend court, had to go to school, and finished their sentence in the middle of the program). This research only analyzed data from young inmates who complete all the sessions. By the end of this program, 20 inmates were participating in all of the sessions.

\section{Instrument}

Beck Anxiety Inventory was used to measure the young offender's level of anxiety before and after they attended the Beta Rasa program. The Indonesian version of the Beck Anxiety Inventory (BAI) was adapted by Ginting et al. (2013). This scale consists of 21 items and has two aspects, the physiological aspect (17 items) and the affective aspect (4 items). The reliability coefficient of this scale was 0.86 . The construct validity of BAI was tested with Beck Depression Inventory. The result shows that there was a correlation between BAI and BDI with $r=0.52$ and $p<0.01$ (Ginting et al., 2013). We used theoretical norms to categorize the levels of anxiety. Data were analyzed using paired sample t-test.

\section{Research Design}

This study was a quasi-experiment using one group with a pretest-posttest design. Pretest and posttest measurements were performed to determine the change of anxiety level before and after participating in Beta Rasa Program. This study only used one experimental group without a control group.

\section{Procedures}

Beta Rasa Program is an emotion regulation program developed according to the emotion regulation technique by Knell (2009). Beta Rasa Program consists of 4 sessions, with 60 - 90 minutes for each session. Previous studies showed that young offenders tend to have a practical way of thinking (Predescue, 2013; Wallinius et al. 2019). Taking consideration of such findings, researchers arranged the program to better suit them as shown in Table 1. 
Table 1.

Session of Beta Rasa Program

\begin{tabular}{|c|c|c|c|}
\hline $\begin{array}{l}\text { Step of Emotion } \\
\text { Regulation }\end{array}$ & Session Name & Purpose & Technique \\
\hline $\begin{array}{l}\text { Knowledge and } \\
\text { understanding } \\
\text { about emotion }\end{array}$ & $\begin{array}{l}\text { Emotion } \\
\text { identification }\end{array}$ & $\begin{array}{l}\text { To have knowledge about } \\
\text { emotions }\end{array}$ & $\begin{array}{l}\text { Psycho-education, } \\
\text { Role play }\end{array}$ \\
\hline $\begin{array}{l}\text { Knowledge and } \\
\text { understanding } \\
\text { about emotion }\end{array}$ & $\begin{array}{l}\text { Emotion } \\
\text { labeling }\end{array}$ & $\begin{array}{l}\text { To help young offenders } \\
\text { being aware of their own } \\
\text { emotion }\end{array}$ & $\begin{array}{l}\text { Termometer Rasa } \\
\text { (emotion tracking } \\
\text { sheet) } \\
\text { Group discussion }\end{array}$ \\
\hline $\begin{array}{l}\text { Ability to identify } \\
\text { emotional triggers } \\
\text { or events }\end{array}$ & $\begin{array}{l}\text { Emotional } \\
\text { triggers } \\
\text { identification }\end{array}$ & $\begin{array}{l}\text { To help young offender } \\
\text { being more cautious with } \\
\text { emotional triggers }\end{array}$ & $\begin{array}{lr}\text { Group discussion } \\
\text { with } \\
\text { Perasaan" }\end{array}$ \\
\hline Coping skill & Coping skill & $\begin{array}{l}\text { To help young offender } \\
\text { found new strategy to } \\
\text { manage their emotion }\end{array}$ & $\begin{array}{l}\text { Group discussion } \\
\text { Relaxation }\end{array}$ \\
\hline
\end{tabular}

This experiment was run by two clinical psychologists as facilitators, and four psychology major students as co-facilitators that had been trained to administer Beta Rasa Program.

\section{Result}

The anxiety level of 20 young offenders was categorized based on the theoretical norm. The result is described in Table 2.

Table 2.

Young Offender's Level of Anxiety

\begin{tabular}{lccc}
\hline \multicolumn{1}{c}{ Level } & Score Range & Pretest & Posttest \\
\hline Severe & $61-73$ & $13(65 \%)$ & $12(60 \%)$ \\
Moderate & $48-60$ & $4(20 \%)$ & $4(20 \%)$ \\
Mild & $35-47$ & $3(15 \%)$ & $2(10 \%)$ \\
Low & $<35$ & $0(0 \%)$ & $1(5 \%)$ \\
\hline
\end{tabular}


Further analysis was conducted to categorize anxiety based on the two aspects of BAI. The result is described in Table 3.

Table 3

Young Offender's Level of Anxiety Based on Aspects

\begin{tabular}{lcccccc}
\hline \multicolumn{1}{c}{ Level } & Score Range & Pretest & Posttest & $\begin{array}{c}\text { Score } \\
\text { Range }\end{array}$ & Pretest & Posttest \\
& & & & $10-12$ & $4(20 \%)$ & $2(10 \%)$ \\
Severe & $39-51$ & $1(5 \%)$ & $0(0 \%)$ & $10)$ & $8(40 \%)$ & $7(35 \%)$ \\
Moderate & $26-38$ & $8(40 \%)$ & $7(35 \%)$ & $7-9$ & $5(25 \%)$ & $7(35 \%)$ \\
Mild & $13-25$ & $8(40 \%)$ & $11(55 \%)$ & $4-6$ & $3(15 \%)$ & $4(20 \%)$ \\
Low & $0-12$ & $3(15 \%)$ & $2(10 \%)$ & $0-3$ & & \\
\hline
\end{tabular}

\section{Assumption testing}

Normality test using Kolmogorov-Smirnov showed that all two data sets have followed a normal distribution with $\mathrm{p}>0.05$.

\section{Hypothesis testing}

Data obtained from two-time measurements of young offender's anxiety was examined using paired sample t-test. A paired-samples t-test was conducted to compare young offender's anxiety before and after receiving the Beta Rasa Program. There was a significant difference in the scores for before the program $(\mathrm{M}=31.9)$ and after receiving the program $(M=27.55)$ conditions; $t(19)=2.116, p=0.048$. The results suggested Beta Rasa Program could reduce young offender's anxiety in LPKA Kupang. An effect size analysis was conducted and the result showed that the effect size of the Beta Rasa Program was 0.41. It means Beta Rasa Program has a moderate effect to reduce young offender's anxiety in LPKA Kupang.

\section{Discussion}

Data analysis revealed that the hypothesis of this research was accepted. Beta Rasa as an emotion regulation program can reduce young offender's anxiety. Data analysis showed that there was a significant difference in the 2-time measurement of young offender's anxiety with $t(19)=2.116, p=0.048$. The results in table 2 and table 3 showed that the level of anxiety in inmates with severe conditions decreased. This result is consistent with several studies that found the effectiveness of emotion regulation programs in reducing anxiety (Compare et al., 2014; Lennarz et al., 2018; Renna et al., 2018; Wirtz et al., 2014).

The emotion identification session helped young offenders in LPKA Kupang to be more aware of their day-to-day emotions. They learned about various types of emotions, not only anger as before. By the end of the first session, they did not only understand but also could 
express and keep track of their own emotions. Research shows that emotional awareness high correlated with anxiety (Veek et al., 2012). This program also helps young offenders to be aware of emotional triggers. It makes young offenders more alert with surrounding situations and then managed their behaviors to anticipate the triggers. Knell (2009) stated that children who learn to be more aware of emotional triggers can regulate their emotions better.

The session about coping skills in Beta Rasa Program helped young offenders to control their responses when unpredictable situations happened. They learned to do more adaptive behavior when experiencing negative emotions; such as deep breathing, walking out, praying, singing, writing, and sharing with others. Research showed that group coping skill intervention helps to reduce anxiety symptoms (Craig et al., 2017).

There are several reasons why the effect of the Beta Rasa program was only on a moderate level. The first reason is the inconsistency of participants. Young offenders in LPKA Kupang had a lot of duties such as cooking or having to attend the trial so that some of them could not fully attend this program. Even if they joined all of the four sessions, sometimes they got calls from the officers. They had to go out of the program room and joined again after a while. It caused some of them unable to participate in every step of the sessions. The second reason is there are factors like age that are actually related to emotion regulation development. The study showed that age has a positive correlation with emotion regulation (Asbrand et al., 2016). The older a person gets, the emotional regulation will be better. Young offenders in this study were in the adolescence period, and which was why their emotion regulation was still in the development process (Asbrand et al., 2016).

Another reason for the moderate effect size can be explained in the coping skill step. The result of the group discussion focused more on the expressive suppression strategy. This strategy focused on the inhibition of emotional expression (Gross, 2015). Most of the strategies suggested by the young offenders on group discussion focused on how to shift their attention from their feelings at that time. As an example, when they felt angry they would try to walk out from the cause. When they felt sad they will try to do any other activity (such as singing, reading, writing, et cetera) that will distract them from the sadness. Gross (2015) explained that people who use expressive suppression strategies tend to avoid expressing their feelings openly. The overuse of expressive suppression strategy may have negative effects such as lower psychological well-being (Gross, 2015).

There was also a new finding in this study that suggests the young offenders in LPKA believed that men are not supposed to show what they feel. In the after-program interview, the researchers found that young offenders in LPKA Kupang believed that it was inappropriate for them to express their emotions. From a young age, their parents do not accustom the children to communicate their feelings. Children also learn to model their parents' emotional responses when facing problems. Parents, especially fathers, transfer their belief that a man is supposed to be a strong figure and it is normal for a boy to receive physical punishment. They continued to carry this belief during their detention in LPKA Kupang. They believed that the physical punishment they received from the officers was 
normal. Studies showed that there is a strong correlation between the parenting process and emotion regulation ability (Asbrand et al., 2016; Kim \& Page, 2013; Read et al., 2018). These findings provide a new perspective on how parental belief, especially fathers, greatly influences children's emotion regulation abilities.

In Indonesia, research about emotion regulation programs is still limited, especially on the subject of young inmates. The findings of this study can become a basis for the development of programs that focus on mental health problems in prison, specifically among young offenders.

This study had several limitations, which should be taken into account when interpreting and generalizing the results. First, this study did not establish a control group due to limited access to include all young offenders as participants. The absence of a control group threatened the internal validity of this experiment. We cannot fully understand whether the change in young offenders' anxiety was caused only by the Beta Rasa emotion regulation program or not. The second limitation was there was no manipulation check in this research. To counter this limitation, we used a session indicator observation sheet to evaluate whatever or not the purpose of each session was achieved by every participant. The last limitation was the inconsistent number of participants who joined each session.

\section{Conclusion}

The study concluded that Beta Rasa as an emotion regulation program can reduce young offender's anxiety in LPKA Kupang. The effect size of this program was 0.41 . This means Beta Rasa Program has a moderate effect in reducing anxiety.

\section{Suggestion}

There are several suggestions for further study. The first one is to use a control group (even if it was a non-equivalent control group) and conducting a manipulation check. For future study in LPKA Kupang, we suggest doing better coordination with the officers to make sure that every inmate could be duty-free on the program days and thus, would be able to fully attend the treatments. We also suggest for further study to explore more on the correlation between East Nusa Tenggara's culture, parenting values, and emotion regulation among young offenders in the juvenile detention center.

\section{References}

Asbrand, J., Svaldi, J., Krämer, M., Breuninger, C., \& Caffier, B. (2016). Familial accumulation of social anxiety symptoms and maladaptive emotion regulation. Plos One, 11(4): e0153153. http://doi.org/10.1371/journal.pone.0153153

Beck, A. T. (1993). Cognitive therapy: past, present, and future. Journal of Consulting and Clinical Psychology, 61(2), 194 - 198 
Benu, J. M. Y., Manafe, R. P., Junias, M., Dubu, R., \& Nope, S. (2019). My potrait in jail: psychological description of young offender in LPKA Kupang. In Tentama. F., Situmorang. N. Z., \& Taliep. N (Eds.), Proceedings of International Conference on Community, Psychology, Humanization, and Religio-Culture (pp. 101 - 106)

Chaplo, S., Kerig, P., Bennett, D., \& Modrowski, C. (2015). The roles of emotion dysregulation and dissociation in the association between sexual abuse and self-injury among juvenile justice-involved youth. Journal of Trauma $\mathcal{E}$ Dissociation, 16, 272-285. http://doi.org/10.1080/15299732.2015.989647

Compare, A., Zarbo, C., Shonin, E., Gordon, W., \& Marconi, C. (2014). Emotional regulation and depression: a potential mediator between heart and mind. Cardiovascular Psychiatric and Neurology, 20(14), 1 -10. http://doi.org/10.1155/2014/324374

Craig, J., Miner, D., Tasneem, R., Miller, J., Zanussi, L. (2017). Piloting a coping skills group intervention to reduce depression and anxiety symptoms in patiens awaiting kidney or liver transplant. Health \& Social Work, 42(1), 44 - 54. http://doi.org/10.1093/hsw/hlw064

Craske, M. G., Rauch, S. L., Ursano, R., Prenoveau, J., Pine, D. S., \& Zinbarg, R. F. (2009). Review: What is an anxiety disorder? Depression and Anxiety, 26, 1066-1085

Demorest. (2019). Anger, Compassion, and Happiness as Antidotes for Sadness. The $\begin{array}{llll}\text { American Journal of } & \text { 132(2), }\end{array}$ http://doi.org/10.1080/17439760.2019.1627399

Direktorat Jenderal Permasyarakatan. (2019). Kepala LPKA Kupang : Banyak warga binaan yang tidak tamat SD. http://www.ditjenpas.go.id/kepala-lpka-kupang-banyak-warga-binaanyang-tidak-tamat-sd

Ginting. H., Naring. G., Van Der Veld. W., Srisayekti. W., Becker. E. (2013). Validating the Beck Depression Inventory-II in Indonesia's general population and coronary heart disease patients. International Journal of Clinical and Health Psychology, 13, 235 - 242

Gross, J. (2015). Emotion regulation: current status and future prospects. Psychological inquiry, 26, 1-16. http://doi.org/10.1080/1047840X.2014.940781

Gruhn, M. A. \& Compas, B. E. (2020). Effects of maltreatment on coping and emotion regulation in childhood and adolescence: A meta-analytic review. Child Abuse $\mathcal{E}$ Neglect, 103, 104446. https://doi.org/10.1016/j.chiabu.2020.104446

Hadjam, M. N. R. (2014). Studi eksplorasi lapas. Fakultas Psikologi, Universitas Gadjah Mada. Haghighat, M., Tabatabaee, S. M., \& Boogar, I. R. (2014). Relation of anxiety, sleep disorders, and drug abuse with patient's tendency toward sedative drugs in Semnan Prison. Asian Journal of Medical and Pharmaceutical Researches, 4(1), 41-45.

Hamzah, I., Muhammad, A., Subarkah, M. Z., Rama, T. A., Agus, M. A., Awibowo, A. D. A., Trisnoputro, Y. N. A., \& Maslihah, S. (2020). Psikologi Penjara: Penerapan Psikologi dalam Proses Pemasyarakatan. Ainun Media.

Heinzen, H., Koehler, D., Smeets, T., Hoffer, T., \& Huchzermeir, C. (2011). Emotion regulation in incarcerated young offenders with psychopathic traits. The Journal of $\begin{array}{lllll}\text { Forensic Psychiatry } & \text { E } & \text { Psychology, 809-833. }\end{array}$ http://doi.org/10.1080/14789949.2011.623171 
Kim, H., \& Page, T. (2013). Emotional bonds with parents, emotion regulation, and school related behavior problems among elementary school truants. Journal Child and Family Studies, 22, 869 - 878. http://doi.org/10.1007/s10826-012-9646-5

Knell, S. (2009). Cognitive behavioral play therapy: theory and application. In A. A. Drewes (Ed.), Blending play therapy with cognitive behavioral therapy: Evidence-based and other effective treatments and techniques (pp.177-134). John Wiley \& Sons, Inc.

Kingston, D. A., Yates, P. M., \& Firestone, P. (2012). The self-regulation model of sexual offending: Relationship to risk and need. Law and Human Behavior, 36(3), 215-224. http://doi.org/10.1037/h0093960

Lennarz, H.K., Hollenstein, T., Lichtwarck-Aschoff, A., Kuntsche, E., \& Granic, I. (2018). Emotion regulation in action: Use, selection, and success of emotion regulation in adolescents' daily lives. International Journal Behavior Development, 43(1), 1-11. http://doi.org/10.1177/016502541875549

Mennin, D., Fresco, D., Pitter, M., \& Heimberg, R. (2015). An open trial of emotion regulation therapy for generalized anxiety disorder and cooccurring depressin. Depression and Anxiety, (32), 614-623. http://doi.org/10.1002/da.22377

Milojevich. H., Machlin. L., Sheridan. M. (2020). Early adversity and children's emotion regulation: Differential roles of parent emotion regulation and adversity exposure. $\begin{array}{llll}\text { Development } \quad \text { and } & \text { Psychopathology, }\end{array}$ https://doi.org/10.1017/S0954579420001273

Patrika. F. J. (2018). Effektifitas pelatihan regulasi emosi untuk menurunkan stress dan meningkatkan kualitas hidup pada penderita diabetes militus tipe II. Persona: Jurnal Psikologi Indonesia, 7(2), 135 - 150. https://doi.org/10.30996/persona.v7i2.1701

Predescu, M. (2013). An analysis of the relation between IQ and crime in the European contries [Paper presentation]. SPECTO, Timisoara, Romania.

Read, D., Clark, G., Rock, A., \& Coventry, W. (2018). Adult attachment and social anxiety: the mediating role of emotion regulation strategies. Plos One, 13(12), e0207514. https://doi.org/10.1371/journal.pone.0207514

Renna, M., Seeley, S., Heimberg, R., Etkin, A., Fresco, D., \& Mennin, D. (2018). Increased attention regulation from emotion regulation therapy for generalized anxiety disorder. Cognitive Therapy Research, 42, 121 - 134. http://doi.org/10.1007/s10608-017-9872-7

Robertson, L., Aboaja, A., Walker, D.-M., Vostanis, P., Witt, K. G., Chakrabarti, I., Perry, A. E., \& Townsend, E. (2020). Interventions for mood, anxiety disorders or self-harm in young offenders. Cochrane Database of Systematic Reviews, 10, CD013768. https://doi.org/10.1002/14651858.CD013768

Speilberger, C. D., \& Sarason, I. G. (1986). Stress and Anxiety: Source Book of Theory and Research. Hemisphere Publishing Corporation

Stanley, M.A., Diefenbach, G. J., \& Hopko, D.R. (2004). Cognitive behavioral treatment for older adults with generalized anxiety disorder: A therapy manual for primary care settings. Behavior Modification, 28(1), 73-111. https://doi.org/10.1177/0145445503259259 
Syahadat, Y. M. (2013). Pelatihan regulasi emosi untuk menurunkan perilaku agresif pada anak. Humanitas, 10(1), 19-36. http://dx.doi.org/10.26555/humanitas.v10i1.326

Veek, S., Nobel, R., \& Derkx, H. (2012). The relatiohship between emotion awareness and somatic complain in children and adolescents: Investigating the mediating role of anxiety and depression. Psychology \& Health, 27(11), 1359-1374. http://doi.org/10.1080/08870446.2012.685738

Velotti, P., Garofalo, C., Callea, A., Bucks, R., Roberton, T., \& Daffern, M. (2016). Exploring anger among offenders: The role of emotion dysregulation and alexithymia. Psychiatry, Psychology, and Law, 24(1), 128-138. http://doi.org/10.1080/13218719.2016.1164639

Wallinius, M., Nordholm, J., Wagnstrom, F., \& Billstedt, E. (2019). Cognitive functioning and aggressive antisocial behaviors in young violent offenders. Psychiatric Research, 272, 572-580. https://doi.org/10.1016/j.psychres.2018.12.140

Wenar, C., \& Kerig, P. (2000). Developmental psychopathology: From infancy through adolescence (4th ed.). McGraw-Hill.

WHO \& ICRC. (2014). Information sheet: Mental health and prisons. World Health Organization

Wirtz, C., Radkovsky, A., Ebert, D., \& Berking, M. (2014). Successful application of adaptive emotion regulation skills predicts the subsequent reduction of depressive symptom severity but neither the reduction of anxiety nor the reduction of general distress during the treatment of major depressive disorder. PLoS One, 9(10), e108288. http://doi.org/10.1371/journal.pone.0108288

Young, K., Sandman, C., \& Craske, M. (2019). Positive and negative emotion regulation in adolescene: links to anxiety and depression. Brain Science, 9(76), 1-20. http://doi.org/10.3390/brainsci9040076

Yunialia. E. M., \& Suharto. I. P. S. (2020). Penurunan tingkat perilaku agresif pada remaja putra dengan terapi regulasi emosi. Jurnal Keperawatan Jiwa, 8(3), 361 - 368. 